\title{
Consideration for an optimal and practical approach to hysteroscopic adhesiolysis of intrauterine adhesions
}

\author{
Tamisa Koythong, Xiaoming Guan \\ Division of Minimally Invasive Gynecologic Surgery, Department of Obstetrics and Gynecology, Baylor College of Medicine, Houston, Texas, USA \\ Correspondence to: Xiaoming Guan. Baylor College of Medicine, 6651 Main St, Suite 1020, Houston, Texas, 77030, USA. Email: xiaoming@bcm.edu. \\ Provenance and Peer Review: This article was commissioned by the editorial office, Annals of Translational Medicine. The article did not undergo \\ external peer review. \\ Comment on: Zhao X, Zhang A, Gao B, et al. Cold scissors ploughing technique in hysteroscopic adhesiolysis: a comparative study. Ann Transl Med \\ 2020;8:50.
}

Submitted Feb 26, 2020. Accepted for publication Mar 09, 2020.

doi: 10.21037/atm.2020.03.119

View this article at: http://dx.doi.org/10.21037/atm.2020.03.119

Intrauterine adhesions (IUA) as it relates to menstrual irregularities, infertility, and pelvic pain was first described by Fritsch in 1894, and then again by Asherman in 1950 $(1,2)$. Its prevalence has been determined to vary anywhere between $0.3-21.5 \%$ (3). Pregnancy-related dilatation and curettage $(\mathrm{D} \& \mathrm{C})$, a procedure that has been estimated to have occurred between $16-32 \%$ of women, is typically thought to be the most common cause of intrauterine adhesions, however approximately $31.3-45.5 \%$ of women can also develop intrauterine adhesions after hysteroscopic myomectomy (4). More primitive interventions were initially described to address these adhesions such as cervical probing and blind dilation and curettage, but with the advent of hysteroscopy came development of more refined techniques for adhesiolysis under direct endoscopic visualization. Two important considerations in performing successful adhesiolysis surgery are: (I) restoring normal uterine cavity and contour with promotion of normal endometrial growth, and (II) decreasing the risk of recurrence of intrauterine adhesions, which can occur in $50 \%$ of severe cases and $21.6 \%$ of moderate cases of IUA $(5,6)$. How exactly to improve the fertile environment through hysteroscopic surgery is still challenging for most gynecologists. With advancements in technology, there are now a multitude of available hysteroscopic instruments and methods for use, but there is however no consensus on the "best" approach to intrauterine adhesions for optimal patient outcomes.

Zhao et al. (7) recently performed a retrospective study comparing outcomes, safety and efficacy of different approaches to hysteroscopic adhesiolysis of intrauterine adhesions. These authors are also the first to officially describe a "ploughing technique" with cold scissors that eliminates the use of electrocautery during adhesiolysis, which although has the advantage of the ability to obtain hemostasis during resection can also ironically increase the risk for the formation of post-procedure intrauterine adhesions through potential endometrial thermal damage (8-10). Additionally, addressed in this article is the need for resection of additional scar tissue during adhesiolysis, which is thought to be critical for successful restorement of the growth of normal endometrial tissue as scar tissue can prevent adequate blood supply from reaching the endometrium $(7,8)$. Therefore, this study is important and practical as it is the first to compare immediate and long term outcomes of different techniques of hysteroscopic adhesiolysis.

One hundred seventy-nine patients who met enrollment criteria in this retrospective study were analyzed according to subsets in how their hysteroscopic adhesiolysis was performed: ploughing group (PG), in which cold scissors were used to resect adhesions and scar tissue, traditional group (TG), in which cold scissors were used to resect adhesions and scar tissue left alone, and electrosurgical group (EG), in which an energy L-hook electrode and resectoscope was used to resect adhesions and scar tissue left alone. Although the study states that the same surgeon graded each patient's intrauterine adhesions in terms of severity based on the American Fertility Society (AFS) classification system, it is unclear how the 
method of resection of these patient's adhesions were then subsequently decided on. Though the authors were able to demonstrate no statistically significant differences between the groups, perhaps a confirmation bias still existed during the scoring of these patient's adhesions which may lend itself more amenable to a particular type of resection (11). Also interesting is the exclusion criteria of patients in whom both tubal ostia were not exposed postoperativelyis this immediately postoperatively, due to a potential ineffectiveness of method? - and additionally in patients in whom intrauterine adhesions had recurred-are these in patients operated on by the same facility or surgeon, when recurrence rates of intrauterine adhesions are found to be between $30-66 \%(12)$ ?

The authors then demonstrated statistically significant outcomes between the three groups. In summary, postoperative AFS scores decreased in all groups-8.48 \pm 1.73 to $2.53 \pm 1.07$ in $P G, 8.74 \pm 1.19$ to $3.17 \pm 1.45$ in $\mathrm{TG}$ and $8.21 \pm 1.64$ to $3.32 \pm 1.29$ in EG-however, however postoperative AFS scores of PG was even more decreased compared to TG and EG $(\mathrm{P}<0.05)$. The authors were able to follow members of each group for 2 years and also demonstrated further significant outcomes in these patients: higher pregnancy rate, higher live birth rate, and lower miscarriage rate of PG when compared to TG and EG. During this 2 year follow up period, the spontaneous pregnancy rate of $\mathrm{PG}$ was $71.6 \%$, which was significantly higher than that of TG (47.7\%) and EG (41.1\%). These numbers not only demonstrate clinical significance but also correlate with findings from other studies $(13,14)$. This data certainly lends itself to the author's conclusions that the "ploughing technique" is safe, feasible, and leads to desirable patient outcomes. It would also have been more informative for readers to include other pregnancy outcomes associated with hysteroscopic adhesiolysis such as placental abnormalities including placenta accreta spectrum, premature delivery, and uterine rupture $(3,15)$.

Studies have been lacking comparing different methods of hysteroscopic adhesiolysis that Zhao et al. begin to address. As demonstrated by their study, PG had statistically and clinically desirable outcomes in regards to fertility. An additional consideration is the instruments used in PG required a smaller caliber operative hysteroscope (6.5 vs. $9.5 \mathrm{~mm}$ in EG) that may be better tolerated by patients in office. Their study begins to open the door for further comparison studies of techniques of hysteroscopic adhesiolysis and, although difficult to design, may lead to development of a randomized controlled trial.

\section{Acknowledgments}

Funding: None.

\section{Footnote}

Conflicts of Interest: Both authors have completed the ICMJE uniform disclosure form (available at http://dx.doi. org/10.21037/atm.2020.03.119). The authors have no conflicts of interest to declare.

Ethical Statement: The authors are accountable for all aspects of the work in ensuring that questions related to the accuracy or integrity of any part of the work are appropriately investigated and resolved.

Open Access Statement: This is an Open Access article distributed in accordance with the Creative Commons Attribution-NonCommercial-NoDerivs 4.0 International License (CC BY-NC-ND 4.0), which permits the noncommercial replication and distribution of the article with the strict proviso that no changes or edits are made and the original work is properly cited (including links to both the formal publication through the relevant DOI and the license). See: https://creativecommons.org/licenses/by-nc-nd/4.0/.

\section{References}

1. Fritsch H. Ein fall von völligem shwaund der Gebahrmutterhöhle nach Auskratzung. Zentralbl Gynaekol 1894:18:1337-42.

2. Asherman JG. Traumatic intrauterine adhesions. Br J Obstet Gynaecol 57:892-6.

3. Deans R, Abbott J. Review of intrauterine adhesions. J Minim Invasive Gynecol 2010;17:555-69.

4. Taskin O, Sadik S, Onoglu A, et al. Role of endometrial suppression on the frequency of intrauterine adhesions after resectoscopic surgery. J Am Assoc Gynecol Laparosc 2000;7:351-4.

5. Pinar H. Intra-uterine adhesions and fertility outcome: how to optimize success? Curr Opin Obstet Gynecol 2007;19:207-14.

6. Yu D, Li TC, Xia E, et al. Factors affecting reproductive outcome of hysteroscopic adhesiolysis for Asherman's Syndrome. Fertil Steril 2008;89:715-22.

7. Zhao X, Zhang A, Gao B, et al. Cold scissors ploughing technique in hysteroscopic adhesiolysis: a comparative study. Ann Transl Med 2020;8:50. 
8. Zhang A, Jamail G, Xue M, et al. Hysteroscopic Intrauterine Adhesiolysis Using the "Ploughing" Technique With Cold Scissors. J Minim Invasive Gynecol 2015;22:934-5.

9. Duffy S, Reid PC, Sharp F. In-vivo studies of uterine electrosurgery. Br J Obstet Gynaecol 1992;99:579-82.

10. Cararach M, Panella J, Ubeda A, et al. Hysteroscopic incision of the septate uterus: scissors versus resectoscope. Hum Reprod 1994;9:87-9.

11. Croskerry, P. Achieving quality in clinical decision making: cognitive strategies and detection of bias. Acad Emerg Med 2002;9:1184-204.

12. AAGL Elevating Gynecologic Surgery. Practice Report: Practice Guidelines on Intrauterine Adhesions Developed in Collaboration With the European Society

Cite this article as: Koythong T, Guan X. Consideration for an optimal and practical approach to hysteroscopic adhesiolysis of intrauterine adhesions. Ann Transl Med 2020;8(11):663. doi: 10.21037/atm.2020.03.119 of Gynaecological Endoscopy (ESGE). J Minim Invasive Gynecol 2017;24:695-705.

13. Chen L, Zhang H, Wang Q, et al. Reproductive Outcomes in Patients With Intrauterine Adhesions Following Hysteroscopic Adhesiolysis: Experience From the Largest Women's Hospital in China. J Minim Invasive Gynecol 2017;24:299-304.

14. Capella-Allouc S, Morsad F, Bertrand C, et al. Hysteroscopic treatment of severe Asherman's syndrome and subsequent fertility. Human Reproduction 1999;14:1230-3.

15. Valle RF, Sciarra JJ. Intrauterine adhesions: hysteroscopic diagnosis,classification, treatment, and reproductive outcome. Am J Obstet Gynecol 1988;158:1459-70. 